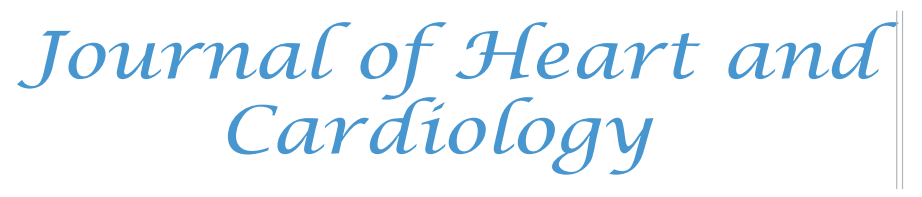

\title{
Using the Stems of Drug Names to Simplify the Prescribing of Cardiovascular Drugs
}

\author{
David M. Paton* \\ Department of Pharmacology, University of Auckland, Auckland, New Zealand
}

*Corresponding author: David M. Paton, MD, Emeritus Professor, Department of Pharmacology, University of Auckland, Auckland, New Zealand, Tel: (250) 756-9334; E-mail: dmpaton38@yahoo.ca

\begin{abstract}
In choosing a generic or official name for a drug the bodies responsible for these decisions follow a number of guidelines. One of these is the use of stems that are reserved for drugs with particular mechanisms of action, clinical use, chemical structure etc. In this article the usefulness of knowing stems is illustrated using the drugs chosen by the Eighth Joint National Committee (JNC 8) as the drugs of first choice for the management of hypertension. The drugs so selected form a limited number of groups identifiable by their stems. Each of these groups has a common mechanism of action; common actions on different organ systems; common clinical uses; and, common unwanted effects. Knowledge of the stems of different groups of drugs is unfortunately not always as useful as in these examples but does assist in identifying some important characteristic of that group thus making stems an important contributor to both undergraduate and postgraduate medical education.
\end{abstract}

Received Date: May 23, 2016

Accepted Date: August 08, 2016

Published Date: August 13, 2016

Citation: Paton, D.M. Using the Stems of Drug Names to Simplify the Prescribing of Cardiovascular Drugs. (2016) J Heart Cardiol 2(2): 76- 79.

DOI: $10.15436 / 2378-6914.16 .030$

\section{Introduction}

Imagine these two scenes: the first is a family physician seeing a new patient who has just arrived from an Asian country. The patient tells him he has been taking a drug called maxisartan for his heart. The doctor is at a loss because he doesn't know the drug at all. The second scene is an end-of-year exam. A student is faced by a question on diabetes. One of the choices is a drug called maxi gliflozin. The student is totally lost as he does not remember ever having heard of this drug at all.

In both cases the knowledge of drug stems would help to locate both drugs in terms of the type of drugs they are. In the first case the suffix -sartan tells the physician that the patient has been on an Angiotensin Receptor Blocker (an ARB). In the second case, the suffix - gliflozin tells the student that the drug is a Sodium Glucose Co-Transporter 2 (SGLT2) inhibitor, in other words a drug that inhibits the reabsorption of glucose in the proximal renal tubule.

Incidentally there are no such drugs as maxisartan or maxi gliflozin available anywhere. In fact, a search on the FDA web site reveals that no generic drug name starts with the prefix maxi ${ }^{[1]}$.

How Drugs Receive their Names: A major problem that faces students starting a pharmacology course are the large number of drug names that need to be learnt. This can also be a problem for physicians as more and more drugs become available as generics as drugs reach the end of their patent lives and thus more drugs become available as generics. Consequently knowledge of their 'proper' or official names becomes ever more important. The purpose of this article is to introduce students and physicians to a system that can hopefully make this task somewhat less daunting!

First, you need to know the difference between the generic and trade names of a drug. The generic name of a drug is the official name of a drug; it is this that you will encounter in textbooks, articles and your examinations. In the United States generic names of drugs are selected by the United States Adopted Names (USAN) Council.

These names must then be approved for international use by the WHO Division of Drug Management and Policies. The generic name for the drug is then known as its International Nonproprietary Name (INN) $)^{[2,3]}$. The trade name of a drug must also

Copyrights: (C) 2016 Paton, D.M. This is an Open access article distributed under the terms of Creative Commons Attribution 4.0 International License. 
be approved by the USAN Council but this can only be used by the pharmaceutical company whose name it is. It is important for medical students and for medical practitioners to get used to using a drug's generic name as it has been selected to reduce errors in prescription $^{[4]}$. It will also facilitate the choice of the cheapest version of a drug by the pharmacist once its patent life has elapsed.

Remember too that we are used to using the term generics for drugs that are no longer patent protected and that generics have their own generic name as well as a trade name. For example, one of the first proton pump inhibitors has the generic name omeprazole and is available under the trade names of Prilosec, Zegerid, Losepine etc.

In choosing a generic name for a drug both the USAN and INN bodies follow a number of guidelines. One of these is the use of stems that are reserved for drugs with particular mechanisms of action, clinical use, chemical structure etc. Stems may be prefixes, suffixes and in stems. One of their stated aims is that the stems for drugs should be useful in medical education. Unfortunately relatively few textbooks make any point of using the naming system used by the USAN and INN. An exception is a review book written by students for students ${ }^{[5]}$ !

In conducting research for this article, the USAN Stem List has been utilized ${ }^{[6,7]}$; this can be found at http://druginfo.nlm. nih.gov/drugportal/jsp/drugportal/DrugNameGenericStems.jsp \\ ${ }^{[6]}$. The search function for FDA approved Drug Products on the Drugs@FDA web site (at http://www.accessdata.fda.gov/scripts/cder/drugsatfda/index.cfm) ${ }^{[7]}$ has been used to search for drugs using mainly suffix stems together with a small number of prefix stems selected from the USAN Stem list.

The results of this study will be detailed according to the main organ system that utilizes drugs with a particular stem and will illustrate how these stems can facilitate the learning of drug names. The only drug stems listed in this article are those where the same suffix stem applies to drugs that have:

a) a common Mechanism Of Action (MOA);

b) common actions on different organ systems;

c) common clinical uses; and,

d) common unwanted effects.

When you see a drug with one of these common suffix stems, you will thus know almost everything you need to know about that drug. It is important to realise that these common features do NOT extend to their pharmacokinetics. These will need to be studied particularly in relation to how their pharmacokinetics influences their use and how interactions with other drugs may occur.

Groups of Drugs Considered First Line Drugs in Treatment of Hypertension: The first example to be examined in some details concerns the drug classes identified as the drugs of first choice for the management of hypertension by the Eighth Joint National Committee (JNC 8) in their "2014 Evidence-Based Guideline for the Management of High Blood Pressure in Adults"[8].

In the JNC8 four groups of drugs are identified as being the groups of drugs of first choice in the treatment of hypertension. They are:

1) Angiotensin Converting Enzyme (ACE) inhibitors;

2) Angiotensin Receptor Blockers (ARBs);

3) Calcium Channel Blockers (CCBs); and,

4) Thiazide diuretics.

How can the use of stems assist in using these new guidelines for hypertension? Table 1 illustrates this.

Table 1: First Line Drugs to Use in Hypertension According To JNC 8.

First Line Drugs in Hypertension

\begin{tabular}{|l|l|l|}
\hline GROUP & DRUGS END IN: & MECHANISM OF ACTION \\
\hline ACE INHIBITORS & $\begin{array}{l}\text {-PRIL } \\
\text {-PRILAT }\end{array}$ & Inhibit Angiotensin Converting Enzyme \\
\hline ARBS & -SARTAN & Angiotensin Receptor Blockers (antagonists) \\
\hline THIAZIDE DIURETICS & -THIAZIDE & $\begin{array}{l}\text { Block } \mathrm{Na}^{+} / \mathrm{Cl}^{-} \text {transporter in distal convoluted } \\
\text { tubule }\end{array}$ \\
\hline $\begin{array}{l}\text { VASCULAR CALCIUM CHANNEL } \\
\text { BLOCKERS }\end{array}$ & -DIPINE & $\begin{array}{l}\text { Block L type Ca } \\
\text { smooth muscle }\end{array}$ \\
\hline $\begin{array}{l}\text { CARDIAC \& VASCULARnels in vascular } \\
\text { CHANNEL BLOCKERS }\end{array}$ & $\begin{array}{l}\text { Block L type Ca } \\
\text { vascular smooth muscle }\end{array}$ \\
\hline
\end{tabular}

The JNC 8 Guidelines also list the drugs found to be effective in Randomized Controlled Trials (RCTs) along with the doses used in these RCTs. These are shown in Table 2 along with how and when the JNC 8 recommends their use: 
Table 2: Details of Suggested Use of $1^{\text {st }}$ Line Drugs to Use in Hypertension According to JNC 8.

Details of Use of $1^{\text {st }}$ Line Drugs in Hypertension

\begin{tabular}{|c|c|c|c|c|}
\hline GROUP & DRUGS LISTED & INITIAL DOSE (mg) & TARGET DOSE (mg) & HOW \& WHEN TO USE \\
\hline ACE INHIBITORS & $\begin{array}{l}\text { Captopril } \\
\text { Enalapril } \\
\text { Lisinopril, }\end{array}$ & $\begin{array}{l}50^{\mathrm{A}} \\
5^{\mathrm{B}} \\
10\end{array}$ & $\begin{array}{c}150-200 \\
20\end{array}$ & $\begin{array}{l}\text { Always use if have renal } \\
\text { impairment }\end{array}$ \\
\hline ARBs & $\begin{array}{l}\text { Candesartan } \\
\text { Eprosartan } \\
\text { Irbesartan } \\
\text { Losartan } \\
\text { Valsartan }\end{array}$ & $\begin{array}{c}4 \\
400^{\mathrm{B}} \\
75 \\
50^{\mathrm{B}} \\
40-80\end{array}$ & $\begin{array}{c}12-32 \\
600-800 \\
300 \\
150 \\
160-130\end{array}$ & $\begin{array}{l}\text { Always use if have renal } \\
\text { impairment \& if cannot take ACE } \\
\text { inhibitor. } \\
\text { Do NOT use ACE Inhibitors and } \\
\text { ARBs at same time }\end{array}$ \\
\hline THIZIDES & $\begin{array}{l}\text { Hydrochlorothiazide } \\
\text { Bendroflumethiazide } \\
\text { Chlorthalidone } \\
\text { Indapamide }\end{array}$ & $\begin{array}{c}12.5-50^{\mathrm{B}} \\
5 \\
12.5 \\
25-50 \\
\end{array}$ & $\begin{array}{c}10 \\
12.5-25 \\
1.25-2.5\end{array}$ & $\begin{array}{l}\text { Use if elderly } \\
\text { or of African extraction }\end{array}$ \\
\hline $\begin{array}{l}\text { VASCULAR CALCIUM } \\
\text { CHANNEL BLOCKERS }\end{array}$ & $\begin{array}{l}\text { Amlodipine, } \\
\text { Nitrendipine }^{\mathrm{C}}\end{array}$ & $\begin{array}{l}2.5 \\
10^{\mathrm{B}}\end{array}$ & $\begin{array}{l}10 \\
20\end{array}$ & $\begin{array}{l}\text { Use if elderly or of African } \\
\text { extraction }\end{array}$ \\
\hline $\begin{array}{l}\text { CARDIAC \& VASCULAR } \\
\text { CALCIUM CHANNEL } \\
\text { BLOCKERS }\end{array}$ & Diltiazem (slow release) & $120-180$ & 360 & $\begin{array}{l}\text { Use if elderly or of African } \\
\text { extraction }\end{array}$ \\
\hline
\end{tabular}

Doses used in RCTs reviewed in JNC $8^{\mathrm{A}}{ }^{[8]}, 2$ doses a day ${ }^{\mathrm{B}}$; 1-2 doses a day ${ }^{\mathrm{C}}$. Not listed on Drugs @ FDA web site.

It is also important to realise that the drugs identified as $1^{\text {st }}$ line for hypertension belong to a small number of drug groups in which the drugs within a given group have a common MOA, same effects on the body, same unwanted effects and same precautions and contraindications. This is illustrated in Table 3.

Table 3: Common Features of $1^{\text {st }}$ Choice Drugs in Hypertension

Features of $1^{\text {st }}$ Line Drugs Used in Hypertension

\begin{tabular}{|l|l|l|l|l|}
\hline GROUP & $\begin{array}{l}\text { MECHANISM of ACTION } \\
\text { (MOA) }\end{array}$ & UNWANTED EFFECTS & CAUTIONS & $\begin{array}{l}\text { CONTRA- } \\
\text { INDICATIONS }\end{array}$ \\
\hline ACE INHIBITORS & $\begin{array}{l}\text { Inhibit angiotensin convert- } \\
\text { ing enzyme }\end{array}$ & $\begin{array}{l}\text { Cough (most common); } \\
\text { Angioedema (often not } \\
\text { recognised) }\end{array}$ & $\begin{array}{l}\text { Hyperkalemia if used } \\
\text { with Aldosterone an- } \\
\text { tagonist or K+- Sparing } \\
\text { diuretic }\end{array}$ & $\begin{array}{l}\text { Always avoid in } \\
\text { PREGNANCY; } \\
\text { Avoid if have bilateral } \\
\text { artery stenosis }\end{array}$ \\
\hline ARBs & $\begin{array}{l}\text { Angiotensin receptor } \\
\text { blockers (antagonists) }\end{array}$ & $\begin{array}{l}\text { Much less likely to cause } \\
\text { cough or angioedema }\end{array}$ & $\begin{array}{l}\text { Hyperkalemia if used } \\
\text { with Aldosterone an- } \\
\text { tagonist or K+-Sparing } \\
\text { diuretic }\end{array}$ & $\begin{array}{l}\text { Always avoid in } \\
\text { PREGNANCY; } \\
\text { Avoid if have bilateral } \\
\text { artery stenosis }\end{array}$ \\
\hline THIAZIDES & $\begin{array}{l}\text { Block Na+/Cl- symporter in } \\
\text { distal convoluted tubule }\end{array}$ & $\begin{array}{l}\text { Hypokalemia } \\
\text { Metabolic acidosis possible } \\
\text { Hyperglycemia } \\
\text { Hyperuricemia }\end{array}$ & $\begin{array}{l}\text { May have allergic reac- } \\
\text { tion to it if have sulfa } \\
\text { allergy }\end{array}$ & $\begin{array}{l}\text { Avoid short acting } \\
\text { CCBs with rapid ab- } \\
\text { sorption as more likely } \\
\text { to cause tachycardia }\end{array}$ \\
\hline $\begin{array}{l}\text { VASCULAR CALCIUM } \\
\text { CHANNEL BLOCKERS }\end{array}$ & $\begin{array}{l}\text { Block L type Ca++ channels } \\
\text { in vascular smooth muscle }\end{array}$ & $\begin{array}{l}\text { Constipation } \\
\text { Edema } \\
\text { Tachycardia }\end{array}$ & $\begin{array}{l}\text { Avoid use if already } \\
\text { taking beta blocker or if } \\
\text { have cardiac failure }\end{array}$ & $\begin{array}{l}\text { Cardiac Failure } \\
\text { Stages C \& D }\end{array}$ \\
\hline $\begin{array}{l}\text { CARDIAC \& VASCULAR } \\
\text { CALCIUM CHANNEL } \\
\text { BLOCKERS }\end{array}$ & $\begin{array}{l}\text { Block L type Ca++ channels } \\
\text { in cardiac \& vascular smooth } \\
\text { muscle }\end{array}$ & $\begin{array}{l}\text { Reduces myocardial con- } \\
\text { tractility. } \\
\text { Bradycardia possible }\end{array}$ &
\end{tabular}

There are a number of points that should be made about the $1^{\text {st }}$ line drugs identified as such in the JNC 8 Report.

a) Captopril has some distinctive features as compared to other ACE Inhibitors. It can cause rashes and disturbances in taste, possible because it possesses a sulfhydryl moiety. It also has to be given twice a day because of its pharmacokinetic properties. These features mean that it probably should not be a first choice if a practitioner wants to prescribe an ACE Inhibitor,

b) A search utilizing the Drugs@FDA web site does not list nitrendipine. Apparently it is not presently available for prescription in the USA. It seems unlikely that any other CCB will be preferable to amlodipine as this can be given once daily and for which there is now a great deal of experience.

c) Many drugs in the four groups identified in the JNC 8 Report are now available as generics. Because of this it is even more important that these drugs be prescribed using their generic names as this is likely to reduce both overall healthcare costs as well as the costs to the individual patient. 
d) A good source of information for patients on many of the drugs in these groups in provided by Consumer Reports Best Buy Drugs. This can be accessed online at http://www.consumerreports.org/health/best-buy-drugs/index.htm

A final example of the value of drug stems in learning about drugs is given in Table 4 where other groups of drugs affecting the cardiovascular system are listed. This has been deliberately restricted to those groups of drugs where the same suffix stem applies to drugs that have:

a) a common mechanism of action (MOA);

b) common actions on different organ systems;

c) common clinical uses; and,

d) common unwanted effects.

Table 4: Groups of drugs affecting the cardiovascular system identified by suffixes and having shared features Drugs affecting CVS with common features

\begin{tabular}{|l|l|l|l|l|}
\hline GROUP & $\begin{array}{l}\text { DRUGS } \\
\text { ENDING IN: }\end{array}$ & $\begin{array}{l}\text { MECHANISM OF } \\
\text { ACTION }\end{array}$ & CLINICAL USES & UNWANTED EFFECTS \\
\hline ALPHA, BLOCKERS & -AZOSIN & $\begin{array}{l}\alpha_{1} \text { Adrenergic receptor } \\
\text { antagonists }\end{array}$ & $\begin{array}{l}\text { Hypertension, } \\
\text { BPH (Benign prostatic } \\
\text { hyperplasia) }\end{array}$ & $\begin{array}{l}\text { Postural hypotension } \\
\left(1^{\text {st }} \text { dose \& with nitrates }\right)\end{array}$ \\
\hline $\begin{array}{l}\text { PHOSPHODIESTERASE } \\
\text { V INHIBITORS }\end{array}$ & -AFIL & $\begin{array}{l}\text { Inhibit phosphodiesterase V } \\
\text { causing increase in cGMP }\end{array}$ & $\begin{array}{l}\text { Erectile dysfunction; } \\
\text { Pulmonary hypertension }\end{array}$ & $\begin{array}{l}\text { Hypotension (with nitrates } \\
\text { \& alpha blockers })\end{array}$ \\
\hline STATINS & -VASTATIN & $\begin{array}{l}\text { Hydroxy-methylglutaryl-coenzyme A } \\
\text { (HMG-CoA) reductase } \\
\text { inhibitors }\end{array}$ & $\begin{array}{l}\text { Hyperlipidemia; } \\
\text { Primary \& secondary } \\
\text { CVS prevention }\end{array}$ & $\begin{array}{l}\text { Myalgia } \\
\text { Rhabdo-myolysis }\end{array}$ \\
\hline
\end{tabular}

Other groups of drugs obviously also affect the cardiovascular system. They too can be identified by their suffixes but either is still being studied to determine their properties, clinical uses and/or unwanted effects, or are already known to not have common features. These groups are as follows:

A) Groups of drugs still under investigation to define clinical uses and unwanted effects:

1. Renin inhibitors end in -KIREN.

2. Low molecular weight heparins end in -PARIN.

3. Direct thrombin inhibitors include those ending in -RUDIN.

4. Thrombolytic agents include those ending in-TEPLASE.

5. Endothelin receptor antagonists end in-SENTAN.

B) Group of drugs with defined actions, clinical uses and unwanted effects sufficiently different so as to prevent their being considered as a homogeneous group.

1. Beta blockers end in -OLOL.

The examples of how drug suffixes considered here will have illustrated their value in learning pharmacology and in the continuing medical education of practitioners. It is important to note that drugs names utilize not only suffixes but also prefixes and infixes. These too can be used in facilitating the learning of pharmacology and therapeutics.

\section{Conflict of Interest: None}

\section{References}

1. FDA. Drugs@,FDA: FDA approved drug products. (2015).

2. Gundersen, L. The complex process of naming drugs. (1998) Ann Intern Med 129(8): 677-678.

3. Carpenter, P.M., Bruce, R.A. Development of an established name: analyzing stem based United States Adopted Naming. (2007) Therapeutic Innovation \& Regulatory Science 41(5): 661-672.

4. Taylor, K.A., Holquist, C.A. More on confusion of drug names. (2013) New Engl J Med 368(20): 1946-1947.

5. Le, T., Bhushan, V. First Aid for the USMLE Step 1 2013. (2013) McGraw-Hill Medical.

6. National Library of Medicine Drug Information Portal. Generic drug names.

7. World Health Organization. The Use of Stems in the Selection of International Nonproprietary Names (INN) for Pharmaceutical Substances, 2013.

8. James, P.A., Oparil, S., Carter, B.L., et al. 2014 evidence-based guideline for the management of high blood pressure in adults: Report from the panel members appointed to the Eighth Joint National Committee (JNC 8). (2014) JAMA 311(5): 507-520.

Journal ISSN: 2378-6914 (online)

Journal Title: Journal of Heart and Cardiology

Short title : J Heart Cardiol
Ommega Online Publishers

E-mail: cardiology@ommegaonline.com

Website: www.ommegaonline.org 